\title{
Isolation and Characterization of
}

\section{Two Hydroxyproline-Containing Glycoproteins}

\section{from Normal Animal Lung Lavage and Lamellar Bodies}

\author{
S. N. Bhattacharyya, M. A. Passero, R. P. DiAugustine, and \\ WILLIAM S. LYNN \\ From the Departments of Biochemistry and Medicine, Duke University \\ Medical Center, Durham, North Carolina 27710, and the National \\ Institute of Environmental Health Sciences, Research Triangle \\ Park, North Carolina 27709
}

\begin{abstract}
A B S T R A C T Two glycopeptides, present in particulate material obtained by pulmonary lavage from normal rabbits, were isolated and characterized. The same two glycopeptides were present in preparations of lamellar bodies from rabbit lung. The estimated molecular weights of the two glycopeptides by sodium dodecyl sulfate-acrylamide gel electrophoresis were found to be 62,000 and 36,000 , and both were found to contain hydroxyproline and relatively high amount of glycine (11 and $15 \%$, respectively). Carbohydrate analysis of the two glycopeptides demonstrated the presence of glucosamine, sialic acid, mannose, fucose, and galactose. Similar glycopeptides of the same molecular weights, and amino acid and carbohydrate compositions have been found in lavage material isolated from lungs of patients with alveolar proteinosis. The data indicate that these two collagen-like glycopeptides are major intra-alveolar proteins in many mammals, including humans.
\end{abstract}

\section{INTRODUCTION}

Alveolar proteinosis (1) is a chronic pulmonary disease of unknown pathogenesis in which the alveoli and terminal bronchioles of the lung are filled with a periodic acid-Schiff $(\mathrm{PAS})^{1}$ positive amorphous material. This material, insoluble in isotonic saline, can be removed in particulate form by pulmonary lavage $(2,3)$. Analysis of the saline-insoluble lavage material by sodium dodecyl

This work was presented in part at the 57th Annual Meeting of the Federation of American Societies for Experimental Biology, Atlantic City, N. J., April, 1973.

Received for publication 15 August 1974 and in revised form 2 December 1974.

${ }^{1}$ Abbreviations used in this paper: PAS, periodic acidSchiff; SDS, sodium dodecyl sulfate. sulfate (SDS)-polyacrylamide gel electrophoresis revealed the presence of three major peptides, the mol wt of which were $69,000,62,000$, and 36,000 (4). The latter two peptides were PAS-positive. Amino acid and carbohydrate analysis of the 62,000 and $36,000 \mathrm{~mol} \mathrm{wt}$ peptides revealed the presence of hydroxyproline, hydroxylysine, glucose, and relatively large amounts of glycine (10 and $15 \%$, respectively). The cause of excessive accumulation of these glycopeptides within alveoli of patients is unknown.

Complete characterization of the particulate proteins of lung lavage material from normal animals has not been previously reported. However, King, Klass, Gikas, Ruch, and Clements $(5,6)$ have identified several peptides in surface-active material isolated from lung lavage fluid of sheep and dogs. These authors found that these surface-active materials had the surface properties predicted for the surfactant lining the alveoli in situ (7).

It has been postulated (8-11) that lamellar bodies (osmiophilic concentric laminar organelles), present in type II epithelial cells of lung, are the storage or secretory form of the surfactant system. It has also been shown that the lamellar bodies and the surfactant activity appear simultaneously in the prenatal lung (12). One component of this surfactant system was shown to be a saturated phospholipid, dipalmitoyl phosphatidylcholine $(13,14)$, also found in lamellar bodies (15). The protein components of the lamellar bodies and the acellular lining fraction of the lung were found to contain mostly an albumin-like protein (15).

In this study, we present compositional data on two glycopeptides isolated from lung lavage material of normal rabbit lung and lamellar bodies that are very similar to the unique glycopeptides isolated from lungs of patients with alveolar proteinosis (4). The function of 
these glycopeptides is not known, but that they occur as major alveolar glycopeptides in many species and accumulate excessively within alveoli of at least one species (human alveolar proteinosis) suggests that the peptides are alveolar secretions, probably derived from lamellar bodies of type II epithelial cells.

\section{METHODS}

Material. Electrophoresis grade acrylamide, bisacrylamide, ammonium persulfate, $\mathrm{N}, \mathrm{N}, \mathrm{N}^{\prime}, \mathrm{N}^{\prime}$-tetramethylethylene diamine and especially pure Bio-Gel P-200 were obtained from Bio-Rad Laboratories, Richmond, Calif. SDS was purchased from Fisher Scientific Co., Pittsburgh, Pa. pHydroxybenzoic acid hydrazide was purchased from Aldrich Chemical Co., Milwaukee, Wis. The ampholyte was purchased from LKB Laboratorie och Kemikaliska Produkter, Stockholm, Sweden. Dansyl chloride was purchased from Pierce Chemical Co., Rockford, Ill.

Preparation of lavage material. Normal rabbits (7-8 lbs) were killed by air embolus, and the lungs were lavaged through the trachea, first with $150 \mathrm{ml}(50 \mathrm{ml}$ three times) of ice-cold isotonic saline and then with $150 \mathrm{ml}(50 \mathrm{ml}$ three times) of cold hypotonic EDTA ( $1 \mathrm{mM}$ EDTA in $5 \mathrm{mM}$ Tris- $\mathrm{HCl}$ buffer, $\mathrm{pH} 7.5$ ). The saline lavage removes all the lipid. Very little protein was found in this lavage. To increase the amount of protein and glycoprotein, an EDTA wash was necessary. The isotonic fluid was discarded and hypotonic lavage fluid (EDTA wash) was centrifuged in the cold at $750 \mathrm{~g}$ for $10 \mathrm{~min}$ to remove alveolar macrophages and other cells. The supernate was then centrifuged in the cold at $25,000 \mathrm{~g}$ for $15 \mathrm{~min}$. The precipitate, in particulate form, obtained by this centrifugation was suspended in $5 \mathrm{mM}$ Tris- $\mathrm{HCl}$ buffer, containing $0.25 \mathrm{M}$ sucrose and $1 \mathrm{mM}$ EDTA ( $\mathrm{pH} 7.5$ ), and homogenized. To remove completely any remaining cells and alveolar organelles, the homogenized material was layered on $30 \%$ sucrose (wt/wt) and centrifuged at $4^{\circ} \mathrm{C}$ at $75,000 \mathrm{~g}$ for $1 \mathrm{~h}$. The material at the interface was removed, suspended in $5 \mathrm{mM}$ Tris- $\mathrm{HCl}$ buffer containing $1 \mathrm{mM}$ EDTA ( $\mathrm{pH} 7.5$ ), and centrifuged at $100,000 \mathrm{~g}$ for $30 \mathrm{~min}$. The precipitate was collected and washed five times with the same buffer. No cells or cellular organelles were present, as observed by electron microscopy. The appearance was that of inhomogeneous vesicles and membranous material.

Isolation of lamellar bodies. Lamellar bodies were isolated from rabbit lungs on a sucrose density gradient as described by DiAugustine (15). The final preparation contained $92 \%$ lipid and $8 \%$ protein. The white pellets obtained were free of other cell organelles, as determined by electron microscopy, and were stored under $\mathrm{N}_{2}$ at $-20^{\circ} \mathrm{C}$ before extraction of glycopeptides. The lipid content of this preparation was reported previously (15).

Analysis. Total protein was determined by the Lowry, Rosebrough, Farr, and Randall method (16), total carbohydrate by the phenol-sulfuric acid method (17) and sialic acid by the thiobarbituric acid method (18). Total lipid was estimated gravimetrically after three extractions with chloroform-methanol $(2: 1 \mathrm{vol} / \mathrm{vol})$ of dry material.

SDS-acrylamide gel electrophoresis was performed according to the method of Weber and Osborn (19). The gels were either stained for protein with coomassie blue or for glycoproteins with PAS reagent (20). Molecular weight estimations for peptides on gels were made with bovine serum albumin, ovalbumin, lactate dehydrogenase, concanavalin $\mathrm{A}$, and cytochrome $c$ as standards.
After chloroform-methanol extractions, the proteins were solubilized in $5 \mathrm{mM}$ Tris- $\mathrm{HCl}$ buffer containing $0.1 \%$ SDS and $0.05 \%$ 2-mercaptoethanol and applied to a Bio-Gel P-200 column $(2.5 \times 80 \mathrm{~cm})$ equilibrated with the same buffer. Elution of peptides was done by the equilibrating buffer. The major peaks were checked for purity by SDS-gel electrophoresis.

Amino acid and carbohydrate analyses. Amino acid and amino sugar analyses were performed by the method of Spackman (21) by a Beckman 120B analyzer (Beckman Instruments, Inc., Fullerton, Calif.) on fractions eluted from the Bio-Gel column, as well as on stained and unstained bands cut from SDS-gels (22). The peptides were hydrolyzed in $6 \mathrm{~N} \mathrm{HCl}$ in an evacuated, sealed tube at $110^{\circ} \mathrm{C}$ for $24 \mathrm{~h}$. The excess gel material was removed by centrifugation when gel bands were used for hydrolysis. Analyses were also done by hydrolyzing the peptide eluted from gels by method of Weiner, Platt, and Weber (23). Recovery of known protein (bovine serum albumin or cytochrome $c$ ) from gels was over $80 \%$. Possible contamination of acrylamide gels with amino acids was checked with blank gels as controls, under the same conditions as above. No impurities could be found. In addition, known proteins (bovine serum albumin, ovalbumin) were eluted from similar gels and analyzed for amino acids. The analyses were identical to those of the untreated starting proteins. Analyses of the peptides isolated from gels were similar to analyses of fractions obtained from Bio-Gel P-200 column. No corrections were made for the destruction or incomplete hydrolysis of the peptides under these conditions. Hydroxylysine and hydroxyproline analyses were done by the method of Piez and Morris (24) and also with a single column (Durrum DC-1A, Durrum Instrument Corp., Palo Alto, Calif.) and temperature gradient. The first $30 \mathrm{~min}$ of elution of amino acids was at $30^{\circ} \mathrm{C}$. The temperature was then increased (over the next $15 \mathrm{~min}$ ) to $60^{\circ} \mathrm{C}$. Both hydroxyamino acids were well separated on this column. Hydroylysine and hydroxyproline analyses were also performed by the colorimetric method $(25,26)$. The content of these amino acids were similar, whether analyzed in the analyzer or by the colorimetric method. Neutral sugars were analyzed by the method of Lee, Johnson, White, and Scocca (27) after the peptides were hydrolyzed with $2 \mathrm{~N}$ trifluoroacetic acid for $3 \mathrm{~h}$ at $110^{\circ} \mathrm{C}$. In addition, glucose was measured with glucose oxidase method as described before (4). Amino sugars were also estimated on the single column of amino acid analyzer after the peptide was hydrolyzed in $4 \mathrm{~N} \mathrm{HCl}$ for $6 \mathrm{~h}$ at $100^{\circ} \mathrm{C}$, as described by Spiro (28). Neutral sugars were also estimated by this method (28). The amounts of various sugars in these glycopeptides estimated by these different methods were the same.

End-group analyses. Qualitative identification of $\mathrm{NH}_{2-}$ terminal amino acid residue of the $36,000-\mathrm{mol}$ wt glycopeptide isolated from Bio-Gel column was performed by the dansyl procedure, as described by Gray (29) with the modifications suggested by Hartley (30). The $\mathrm{NH}_{2}$-terminal amino acid residues of the 62,000 and $36,000 \mathrm{~mol} \mathrm{wt}$ glycopeptides eluted from SDS-acrylamide gels were also determined by the method of Weiner et al. (23). Both methods gave the same single $\mathrm{N}_{\mathrm{H}}$-terminal residue.

Isoelectric focusing. Isoelectric focusing of the 36,000 mol wt glycopeptide in polyacrylamide gels containing $3.5 \%$ acrylamide and in presence of $8 \mathrm{M}$ urea was done by the method of Miller and Elgin (31). $\mathrm{pH}$ 3.5-10 ampholine was used. The $\mathrm{pH}$ gradient obtained was determined by the method of Finlayson (32). The glycopeptide was dia- 
lyzed against $10 \mathrm{M}$ urea containing $1 \%$ 2-mercaptoethanol for $12 \mathrm{~h}$ (one change) before electrofusing.

\section{RESULTS}

Between 2 and $3 \mathrm{mg}$ of lavage precipitate were obtained from the lungs of each rabbit. After purification on sucrose, about $40 \%$ of the total weight of each lavage remained.

It contained $56 \%$ lipid, as estimated after extraction with chloroform-methanol. SDS-acrylamide gel electrophoresis of the delipidated lavage material (Fig. 1C) revealed six major bands of apparent mol wt 75,000, $69,000,62,000,50,000,36,000$, and 25,000 . The PAS staining of these gels (Fig. 1D) indicated two prominent glycopeptides of mol wt 62,000 and 36,000 . Several other glycopeptides were also present in this material, as indicated by the PAS reagent.

Between 0.5 and $1 \mathrm{mg}$ of protein was obtained from the lung lamellar bodies of each rabbit. The phospholipid-to-protein ratio in this preparation was $12: 1$. SDS-acrylamide gel electrophoresis (Fig. 1A) of the delipidated lamellar bodies revealed six major bands of apparent mol wt 75,000, 69,000,62,000, 50,000, 36,000, and 25,000, the most prominent of which was the 69,000 mol wt peptide. The 62,000 and $36,000 \mathrm{~mol}$ wt peptides were also PAS-positive (Fig. 1B). Other PAS-positive bands are also present.

The 36,000 mol wt glycopeptide from lung lavage material was separated by gel filtration on a Bio-Gel P-200 column, as seen in Fig. 2. The $62,000 \mathrm{~mol} \mathrm{wt}$ glycopeptide could not be separated from the 69,000 mol wt peptide in this column. Accordingly, amino acid

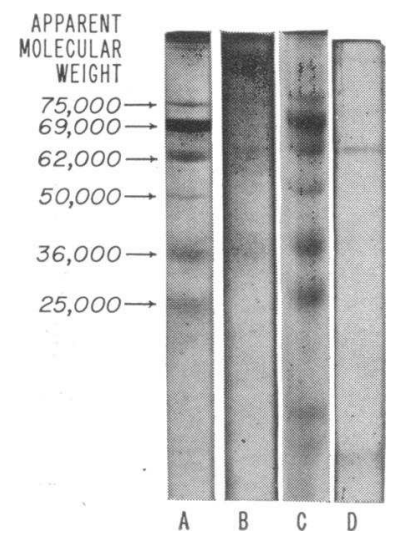

FIGURE 1 SDS-polyacrylamide gel electrophoresis of alveolar lavage sediment and lamellar bodies from rabbit lungs. Electrophoresis was performed with $10 \%$ acrylamide, containing approximately $60 \mu \mathrm{g}$ of protein in A, B, and C, and $40 \mu \mathrm{g}$ in $\mathrm{D}$. A, Lamellar body preparation, stained with coomassie blue; B, Same as A, stained with PAS; C, Alveolar lavage sediment after sucrose density gradient centrifugation, stained with coomassie blue; and D, same as $\mathrm{C}$, stained with PAS.

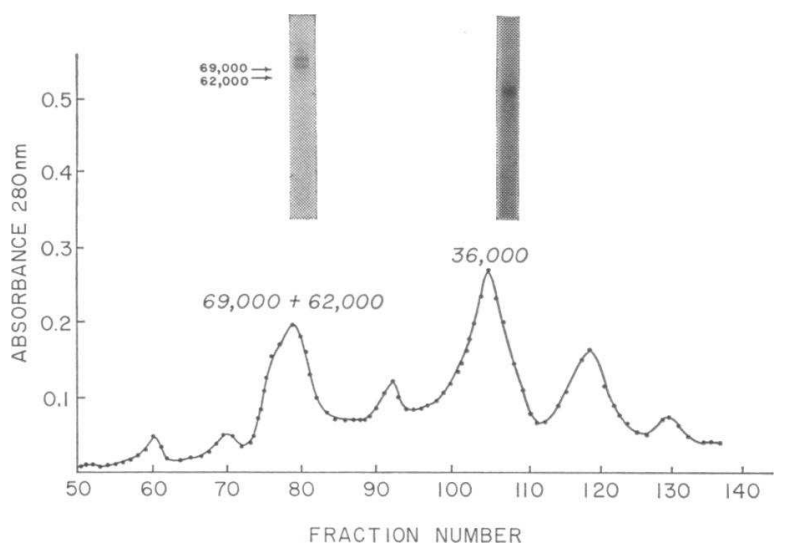

FIGURE 2 Separation of lung lavage peptides of rabbit by gel filtration on Bio-Gel P-200 column in $5 \mathrm{mM}$ Tris- $\mathrm{HCl}$ buffer containing $0.1 \%$ SDS, $0.05 \%$ 2-mercaptoethanol, and $0.02 \%$ sodium azide $(\mathrm{pH} 7.5)$. Column dimensions, $2.5 \times 80$ $\mathrm{cm}$; volume per fraction, $0.8 \mathrm{ml}$. The peaks containing the purified peptides are shown after electrophoresis in SDSpolyacrylamide gels (insets). The electrophoresis was done by the method of Weber and Osborn (19).

analysis on the $62,000 \mathrm{~mol}$ wt glycopeptide was done on gel bands.

Separation of lamellar body peptides on a Bio-Gel P-200 column is given in Fig. 3. The $62,000 \mathrm{~mol} \mathrm{wt}$ peptide could not be separated from the $69,000 \mathrm{~mol} \mathrm{wt}$ peptide. Accordingly, the amino acid analysis of the 62,000 mol wt peptide was done on the gel band. The 36,000 mol wt peptide could easily be separated from other peptides on the Bio-Gel P-200 column, as seen in Fig. 3.

The calculated percentages of the $36,000 \mathrm{~mol} \mathrm{wt}$ glycopeptide in lavage and lamellar bodies are approximately $32 \%$ and $20 \%$, respectively. The percentage of the $62,000 \mathrm{~mol} \mathrm{wt}$ peptide could not be calculated, since we have been unable to separate this glycopeptide from the 69,000 mol wt peptide except by gel electrophoresis.

The material of apparent very high molecular weight that failed to enter the gel (Fig. 1) is an artifact of loading. No high molecular weight protein is seen when the protein is dissolved in a larger volume of solubilizing medium and separated on Bio-Gel P-200 column (Figs. 2 and 3 ).

Preliminary amino acid sequence data and end-group analyses of cyanogen bromide cleavage fragments of the human 36,000 mol wt peptide ${ }^{2}$ suggest that this peptide is homogeneous and contains 310 residues.

Isoelectric focusing (Fig. 4) of the reduced peptide $(36,000)$ from lung lavage and lamellar bodies after $12 \mathrm{~h}$ of dialysis against $8 \mathrm{M}$ urea failed to effect any further resolution. Only one area of protein, $\mathrm{pH} 7.4$,

\footnotetext{
${ }^{2}$ Bhattacharyya, S. N., S. Sahu, and W. S. Lynn. Unpublished observation.
} 


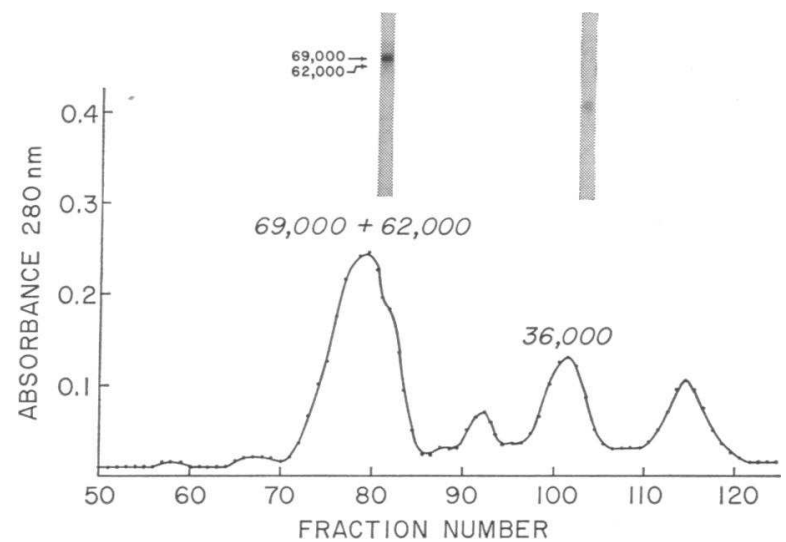

FIGURE 3 Separation of rabbit lung lamellar body peptides by gel titration on Bio-Gel P-200 column in $5 \mathrm{mM}$ Tris- $\mathrm{HCl}$ buffer containing $0.1 \%$ SDS, $0.05 \%$ 2-mercaptoethanol, and $0.02 \%$ sodium azide $(\mathrm{pH} 7.5)$. Column dimensions, $2.5 \times 80$ $\mathrm{cm}$; volume per fraction, $0.8 \mathrm{ml}$. Electrophoresis patterns of the peaks of the purified peptides in the SDS-polyacrylamide gel are shown in the insets. The gel electrophoresis was done by the method of Weber and Osborn (19).

was present. The data from electrofocusing suggest that the peptide is pure.

Amino terminal end-group analysis of the 62,000 and $36,000 \mathrm{~mol}$ wt glycopeptides (Table I) isolated from

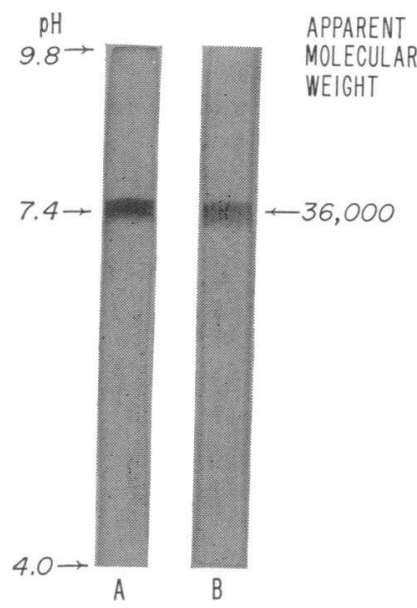

FIgURE 4 Isoelectric focusing of the $36,000 \mathrm{~mol} \mathrm{wt}$ glycopeptide isolated from lavage (A) and lamellar bodies (B) of rabbit lung. Electrophoresis was performed with $3.5 \%$ acrylamide containing $8 \mathrm{M}$ urea and $0.4 \%$ ampholine $(\mathrm{pH}$ 3.5-10.0), by the method of Miller and Elgin (31). Anode at bottom. Direction of migration top to bottom. The glycopeptide was dialyzed against $10 \mathrm{M}$ urea containing $1 \% 2$ mercaptoethanol for $12 \mathrm{~h}$ (one change) before electrofusing. Samples were applied directly to the top of polymerized gel; a constant current of $1 \mathrm{~mA} /$ gel was maintained until a voltage of $200 \mathrm{~V}$ had been reached. A constant voltage of 200 was then maintained until the end of the run $(6 \mathrm{~h}$ total time). About $60 \mu \mathrm{g}$ of protein was applied to gel A and $45 \mu \mathrm{g}$ of protein to gel $\mathrm{B}$.
TABLE I

Amino Acid Composition of Purified Glycopeptides from Rabbit Lung

\begin{tabular}{|c|c|c|c|c|}
\hline \multirow[b]{2}{*}{ Amino acid } & \multicolumn{2}{|c|}{ Lavage glycopeptides } & \multicolumn{2}{|c|}{$\begin{array}{l}\text { Lamellar body } \\
\text { glycopeptides }\end{array}$} \\
\hline & 62,000 & 36,000 & 62,000 & 36,000 \\
\hline Aspartic acid & 96.0 & 81.0 & 95.8 & 80.9 \\
\hline Glutamic acid & 115.9 & 90.5 & 116.0 & 90.5 \\
\hline Threonine & 51.7 & 47.6 & 51.6 & 47.4 \\
\hline Serine & 48.2 & 48.6 & 48.4 & 48.7 \\
\hline Proline & 53.6 & 62.0 & 53.5 & 62.0 \\
\hline Glycine & 110.0 & 148.8 & 110.0 & 148.6 \\
\hline Alanine & 76.2 & 71.0 & 76.1 & 71.1 \\
\hline Half-cystine & 12.4 & 17.4 & 12.3 & 17.6 \\
\hline Valine & 63.5 & 65.6 & 63.5 & 65.8 \\
\hline Methionine & 14.0 & 10.6 & 14.1 & 10.6 \\
\hline Isoleucine & 29.6 & 44.5 & 29.5 & 44.6 \\
\hline Leucine & 86.0 & 96.4 & 86.1 & 96.6 \\
\hline Tyrosine & 46.7 & 33.8 & 46.7 & 33.8 \\
\hline Phenylalanine & 50.2 & 41.8 & 50.1 & 41.9 \\
\hline Lysine & 63.0 & 42.5 & 63.1 & 42.5 \\
\hline Histidine & 24.8 & 23.6 & 25.0 & 23.5 \\
\hline Arginine & 50.3 & 58.4 & 50.6 & 58.4 \\
\hline 4 Hydroxyproline & 8.2 & 12.0 & 8.3 & 11.9 \\
\hline Hydroxylysine & 0 & 0 & 0 & 0 \\
\hline $\mathrm{NH}_{2}$-terminus & Valine & Threonine & Valine & Threonine \\
\hline
\end{tabular}

Amino acid compositions are expressed as residues/1,000 amino acids. The results are average of triplicate analyses of 24-h hydrolysates; 'no corrections have been made for destruction or incomplete hydrolysis.

presence of only one $\mathrm{NH}_{2}$-terminal residue for each human or rabbit lavage or lamellar bodies indicated the glycopeptide, i.e., valine and threonine, respectively. These data also indicate that these glycopeptides are probably pure.

Amino acid compositions of the two glycopeptides $(62,000$ and $36,000 \mathrm{~mol} \mathrm{wt})$ from lavage material and lamellar bodies of rabbit lungs are given in Table $I$. Both glycopeptides contain the same content of hydroxyproline as well as other amino acids, whether isolated from lavage material or lamellar bodies. Hydroxylysine was not found in the glycopeptides isolated from lung lavage material or from lamellar bodies.

There is also a major band of mol wt 69,000 in gels of lavage material and in lamellar body preparations. This peptide contained no carbohydrate, and had an amino acid composition similar but not identical to rabbit albumin from commercial sources. The content of glycine was high, while the content of valine was low in comparison to the rabbit albumin. That the high glycine content is not an artifact contributed by acrylamide gel was shown by analyzing pure rabbit, bovine, and human albumin, isolated electrophoretically on SDS-acrylamide gels. The glycine content of the authentic preparation was $1-2 \%$, in good agreement with the known content of glycine in albumin (33). A similar observation (4) was made in the case of the $69,000 \mathrm{~mol}$ wt peptide isolated from gels of lung lavage material of patients with alveolar proteinosis. This peptide, iso- 
TABLE II

Carbohydrate Composition of Purified Glycopeptides from Rabbit Lung

\begin{tabular}{lccccc}
\hline & \multicolumn{3}{c}{ Lavage glycopeptides } & & \multicolumn{2}{c}{$\begin{array}{c}\text { Lamellar body } \\
\text { glycopeptides }\end{array}$} \\
\cline { 2 - 3 } \cline { 5 - 6 } Carbohydrate & 62,000 & 36,000 & & 62,000 & 36,000 \\
\hline Sialic acid & 1.20 & 1.50 & & 1.22 & 1.50 \\
Mannose & 1.50 & 2.00 & & 1.50 & 1.95 \\
Fucose & 0.60 & 0.78 & & 0.60 & 0.76 \\
Galactose & 1.00 & 2.20 & & 1.00 & 2.20 \\
Glucosamine & 0.62 & 0.60 & 0.62 & 0.60 \\
\hline
\end{tabular}

The compositions are expressed as percentage of carbohydrate per peptide. The methods of analysis are given in the text. Results are average of triplicate analyses.

lated from human lavage precipitate, cross-reacts with rabbit antisera to human albumin (4).

The carbohydrate compositions (Table II) of the glycopeptides $(62,000$ and $36,000 \mathrm{~mol} \mathrm{wt})$ from lavage material and lamellar bodies of rabbit lungs indicated the presence of sialic acid, glucosamine, mannose, fucose, and galactose in amounts essentially the same as in the glycopeptides isolated from human lungs with alveolar proteinosis, except that glucose was not present in either of the rabbit lung glycopeptides. Although glucose was originally reported in the human glycopeptides, subsequent studies have indicated that the glucose was bound to contaminating glycolipids.

\section{DISCUSSION}

It has been previously reported (4) that the lavage material isolated from lungs of patients with alveolar proteinosis contained two unique glycopeptides of apparent mol wt 62,000 and 36,000 . These glycopeptides, insoluble in saline, were associated with lipid (52\% by weight) and contained hydroxyproline and high amount of glycine.

The results presented in this paper show that the lavage material and the lamellar bodies from normal rabbit lungs also contain two glycopeptides of the same compositions, $\mathrm{NH}_{2}$-terminal amino acid residues, and apparent mol wt $(62,000$ and 36,000$)$ as those found in human lung. Large amounts of lipids are also associated with lung lavage material ( $56 \%$ by weight) and lamellar bodies ( $90 \%$ by weight) from rabbits. Preliminary results " on dog lung lavage material also indicated the presence of two glycopeptides with similar compositions.

The SDS-acrylamide gel patterns, isoelectric focusing, and the qualitative $\mathrm{NH}_{2}$-terminal amino acid analy-

\footnotetext{
${ }^{8}$ Sahu, S., and W. S. Lynn. Unpublished data.

- Bhattacharyya, S. N., M. A. Passero, and W. S. Lynn. Unpublished observation.
}

ses suggest that these glycopeptides are homogeneous. The estimation of molecular weight of the glycopeptides by SDS-acrylamide gel electrophoresis as given here is, however, probably not sufficiently accurate. This is because the carbohydrate and collagen-like portions ${ }^{2}$ of the molecules may influence the rate at which the glycopeptides would migrate through acrylamide gels in SDS. The presence of carbohydrate has led to the overestimation of molecular weights of immunoglobulin chains $(34,35)$. Also collagens and peptides derived from them migrate through acrylamide gels in SDS at a much slower rate than globular proteins of the same molecular weight $(35,36)$. The overestimation of molecular weights of the subunits of human $\mathrm{Clq}$ was also noted by Reid, Lowe, and Porter (37).

It was previously reported (4) that hydroxylysine and glucose were present in the glycopeptides isolated from lavage material of patients with alveolar proteinosis. After careful delipidation of the lavage material from human (alveolar proteinosis) and animal lungs, all the glucose was found to be in two glycolipids ${ }^{8}$ (glucosyl ceramide and the ganglioside, $\mathrm{GM}_{3}$ ). The reported presence of small amounts of hydroxylysine in the glycopeptides from lungs of patients with alveolar proteinosis was an artifact, because the peak indicating hydroxylysine in the amino acid analysis disappeared upon extensive delipidation and further purification of the peptides by Bio-Gel P-200 column. The absence of hydroxylysine in these glycopeptides was also verified by the colorimetric method (25).

The presence of these unique glycopeptides as major peptides in lung lavage material and lamellar bodies in particulate form suggests that the lamellar bodies may be the source of these glycopeptides. The actual biochemical and physiological functions of the lamellar bodies in type II epithelial cells of lungs is not known. Sorokin (38) has reported transformation of the type II cell multivesicular bodies into type II cell lamellar bodies. The presence of multivesicular bodies in the lamellar body fractions during purification procedures also lends support to such a transformation or fusion (15). The mature organelle appears to migrate to the apical area of the type II epithelial cells, where it is secreted.

King et al. $(5,6)$ have described a soluble peptide of mol wt 34,000 in the material lavaged from different animal lungs, but the compositional data on this peptide are not yet available. These authors concluded that this peptide was present in the surface-active material. Since the method of isolation of lavage material in this study is very similar to that of King et al. (5), their peptide may be the same as the $36,000 \mathrm{~mol}$ wt glycopeptide reported here.

The presence of hydroxyproline and a relatively high content of glycine in the 62,000 and $36,000 \mathrm{~mol} \mathrm{wt}$ 
glycopeptides suggests contamination of these peptides by collagen. But these glycopeptides do not contain hydroxlysine and glucose, usually found in collagens or collagen-related proteins of basement membrane (3941). Moreover, the percentages of hydroxyproline and glycine in these glycopeptides are much lower than in collagen. It is also interesting to note that neither of the glycopeptides contain 3-hydroxyproline, known to be present in the basement mambrane (40). The ratio of glucosamine to galactosamine in most basement membrane preparation is $4: 1$ (40), whereas in the alveolar glycopeptides, no galactosamine was found.

The existence of collagenous and noncollagenous sequences in the same polypeptide chain is now well-documented for procollagen (42, 43). Skoza and Mohos (44) have recently reported that glomerular basement membrane preparations consist of two glycoproteins, collagen and sialoprotein. Reid (45) has also shown that one of the subunits of human complement, $\mathrm{Clq}$, contains a short collagen-like sequence, $(\mathrm{Gly}-\mathrm{X}-\mathrm{Y})_{\mathbf{n}}$, in which 5 of 26 of the $Y$ residues are hydroxyproline. In addition, C1q contains hydroxylysine and glucose (45$47)$. Since the alveolar peptides contain no hydroxylysine or glucose, it is likely that they are not derived from C1q (46). The alveolar glycopeptides are, therefore, another example of peptides containing hydroxyproline and high concentration of glycine, and which, like procollagen $(42,43)$ and $\mathrm{Clq}(45)$, may contain collagen-like sequences of $(\mathrm{Gly}-\mathrm{X}-\mathrm{Y})_{\mathrm{n}}$ in one segment of the peptide chain but not in other segments.

As shown by this report, two unique collagen-like glycopeptides are present in particulate form in the lung lavage material and lamellar bodies isolated from normal rabbit. We suggest that these glycopeptides are normal components of alveoli and probably are normal secretory products of type II epithelial cells. That in humans with alveolar proteinosis these glycopeptides accumulate without producing any inflammatory cellular response also suggests that these peptides are normal components of alveoli.

\section{ACKNOWLEDGMENTS}

This investigation was supported in part by National Institutes of Sciences Training Grant ES-00124-06, Veteran's Administration Project 5348-01, and a North Carolina Lung Association Grant.

\section{REFERENCES}

1. Rosen, S. H., B. Castleman, and A. A. Liebow. 1958. Pulmonary alveolar proteinosis. N. Engl. J. Med. 258: 1123-1142.

2. Ramirez-R., J. 1967. Pulmonary alveolar proteinosis: treatment by massive bronchopulmonary lavage. Arch. Intern. Med. 119: 147-156.

3. Kylstra, J. A., D. C. Rausch, D. K. Hall, and A. Spock. 1971. Volume-controlled lung lavage in the treatment of asthma, bronchiectasis and mucoviscidosis. Am. Rev. Respir. Dis. 103: 651-665.

4. Passero, M. A., R. W. Tye, K. H. Kilburn, and W. S. Lynn. 1973. Isolation and characterization of two glycoproteins from patients with alveolar proteinosis. Proc. Natl. Acad. Sci. U. S. A. 70: 973-976.

5. King, R. J., D. J. Klass, E. G. Gikas, and J. A. Clements. 1973. Isolation of apoproteins from canine surface active material. Am. J. Physiol. 224: 788-795.

6. King, R. J., E. G. Gikas, J. Ruch, and J. A. Clements. 1974. Radioimmunoassay of pulmonary surface active material in sheep lung. Am. Rev. Respir. Dis. 110: 273-281.

7. King, R. J., and J. A. Clements. 1972. Surface active material from dog lung. II. Composition and physiological correlations. Am. J. Physiol. 223: 715-726.

8. Macklin, C. C. 1954. The pulmonary alveolar mucoid film and the pneumonocytes. Lancet. 1: 1099-1104.

9. Pattle, R. E. 1955. Properties, function, and origin of alveolar lining layer. Nature (Lond.). 175: 1125-1126.

10. Balis, J. U., and P. E. Conen. 1964. The role of alveolar inclusion bodies in the developing lung. Lab. Invest. 1.3 : 1215-1229.

11. Buckingham, S., H. O. Heinemann, S. C. Sommers, and W. F. McNary. 1966. Phospholipid synthesis in the large pulmonary alveolar cell. Its relation to lung surfactants. Am. J. Pathol. 48: 1027-1041.

12. Buckingham, S., W. F. McNary, Jr., and S. C. Sommers. 1964. Pulmonary alveolar cell inclusions: their development in the rat. Science (Wash. D. C.). 145: 1192-1193.

13. Brown, E. S. 1964. Isolation and assay of dipalmityl lecithin in lung extracts. Am. J. Physiol. 207: 402-406.

14. Morgan, T. E., T. N. Finley, and H. Fialkow. 1965. Comparison of the composition and surface activity of "alveolar" and whole lung lipids in the dog. Biochem. Biophys. Acta. 106: 403-413.

15. DiAugustine, R. P. 1974. Lung concentric laminar organelle. Hydrolase activity and compositional analysis. J. Biol. Chem. 249: 584-593.

16. Lowry, O. H., N. J. Rosebrough, A. L. Farr, and R. J. Randall. 1951. Protein measurement with the Folin phenol reagent. J. Biol. Chem. 193: 265-275.

17. Dubois, M., K. A. Gilles, J. K. Hamilton, P. A. Rebers, and F. Smith. 1956. Colorimetric method for determination of sugars and related substances. Anal. Chem. 28: 350-356.

18. Warren, L. 1959. The thiobarbituric acid assay of sialic acids. J. Biol. Chem. 234: 1971-1975.

19. Weber, K., and M. Osborn. 1969. The reliability of molecular weight determinations by dodecyl sulfatepolyacrylamide gel electrophoresis. J. Biol. Chem. 244: 4406-4412.

20. Glossman, H., and D. M. Neville. 1971. Glycoproteins of cell surfaces. A comparative study of three different cell surfaces of rat. J. Biol. Chem. 246: 6339-6346.

21. Spackman, D. H. 1967. Accelerated amino acid analysis. Methods Enzymol. 11: 3-15.

22. Houston, L. L. 1971. Amino acid analysis of stained bands from polyacrylamide gels. Anal. Biochem. 44: 81-88.

23. Weiner, A. M., T. Platt, and K. Weber. 1972. Amino terminal sequence analysis of proteins purified on a nanomole scale by gel electrophoresis. J. Biol. Chem. $247: 3242-3251$. 
24. Piez, K. A., and L. Morris. 1960. A modified procedure for the automatic analysis of amino acids. Anal. Biochem. 1: 187-201.

25. Blumenkrantz, N., and G. Asboe-Hansen. 1973. An improved method for the assay of hydroxylysine. Anal. Biochem. 56: 10-15.

26. Prockop, D. J., and S. Udenfriend. 1960. A specific method for the analysis of hydroxyproline in tissue and urine. Anal. Biochem. 1: 228-239.

27. Lee, Y. C., G. S. Johnson, B. White, and J. Scocca. 1971. An accelerated system for analysis of neutral sugars in complex carbohydrates. Anal. Biochem. 43: 640-643.

28. Spiro, R. G. 1972. Study of the carbohydrates of glycoproteins. Methods Enzymol. 28: 3-43.

29. Gray, W. R. 1967. Sequential degradation plus dansylation. Methods Enzymol. 11: 469-475.

30. Hartley, B. S. 1970. Strategy and tactics in protein chemistry. Biochem. J. 119: 805-822.

31. Miller, D. W., and S. C. R. Elgin. 1974. Isoelectric focusing of proteins exposed to sodium dodecyl sulfate. Anal. Biochem. 60: 142-148.

32. Finlayson, G. R., and A. Chrambach. 1971. Isoelectric focusing in polyacrylamide gel and its preparative application. Anal. Biochem. 40: 292-311.

33. Schultze, H. E., and J. F. Heremans. 1966. Survey of the plasma proteins. In Molecular Biology of Human Proteins with Special Reference to Plasma Proteins. Elsevier U. M., Amsterdam. 173-235.

34. O'Daly, J. A., and J. J. Cebra. 1971. Chemical and physicochemical studies of the component polypeptide chains of rabbit secretory immunoglobulin A. Biochemistry. 10 : 3843-3850.

35. Shubert, D. 1970. Immunoglobulin biosynthesis. IV. Carbohydrate attachment to immunoglobulin subunits. J. Mol. Biol. 51 : 287-301.

36. Furthmayr, H., and R. Timpl. 1971. Characterization of collagen peptides by sodium dodecyl sulfate-polyacrylamide electrophoresis. Anal. Biochem. 41: 510-516.
37. Reid, K. B. M., D. M. Lowe, and R. R. Porter. 1972. Isolation and characterization of C1q, a subcomponent of the first component of complement, from human and rabbit sera. Biochem. J. 130: 749-763.

38. Sorokin, S. P. 1966. A morphologic and cytochemical study on the great alveolar cell. J. Histochem. Cytochem. 14 : 884-897.

39. Spiro, R. G. 1967. Studies on the renal glomerular basement membrane. Nature of the carbohydrate units and their attachment to the peptide portion. J. Biol. Chem. 242: 1923-1932

40. Kefalides, N. A. 1970. Comparative biochemistry of mammalian basement membranes. In Chemistry and Molecular Biology of the Intercellular Matrix. E. A. Balazs, editor. Academic Press, Inc., New York. 535573.

41. Johnson, L. D., and B. C. Starcher. 1972. Epithelial basement membrane: the isolation and identification of a soluble component. Biochem. Biophys. Acta. 290: 158-167.

42. Bellamy, G., and P. Bornstein. 1971. Evidence for procollagen, a biosynthesis precursor of collagen. Proc. Natl. Acad. Sci. U. S. A. 68: 1138-1142.

43. Bornstein, P., K. Von Der Mark, A. W. Wyke, H. P. Ehrlich, and J. M. Monson. 1972. Characterization of the pro- $\alpha 1$ chain of procollagen. J. Biol. Chem. 247: 2808-2813.

44. Skoza, L., and S. C. Mohos. 1974. Enzymatic solubilization and separation of glomerular collagen and sialoprotein. Lab. Invest. 30: 93-101.

45. Reid, K. B. M. 1974. A collagen-like amino acid sequence in a polypeptide chain of human $\mathrm{Clq}$ (a subcomponent of the first component of complement). Biochem. J. 141 : 189-203.

46. Bhattacharyya, S. N., M. A. Passero, and W. S. Lynn. 1974. Isolation and characterization of human Clq. Biochim. Biophys. Acta. 342: 343-350.

47. Calcott, M. A., and H. J. Muller-Eberhard. 1972. C1q protein of human complement. Biochemistry. 11:34433450. 